\title{
Editor's Note \\ On the Special Public Law Issue and Next Year's
}

This special issue is a cooperative effort of The Review of Politics and American Political Science Association's Section on the Law, Courts, and Judicial Process. A special editorial board and review process was in effect for this issue. That effort was chaired by Samuel Krislov of the University of Minnesota. He was joined by Doris Marie Provine of Syracuse University and Donald P. Kommers of the University of Notre Dame, who kindly served in this capacity even while on leave in this past academic year from his regular duties as chief editor of The Review.

Another special issue with the same range of concern and utilizing the same procedures is planned for the summer of 1993. Manuscripts intended for consideration for this special issue must be submitted no later than February 1, 1993, to The Review of Politics. Submissions should be in accord with the "Instructions to Contributors" found elsewhere in this issue. The editorial board for the special issue particularly encourages manuscripts not focused on the U.S. Supreme Court.

Walter Nicgorski

Acting Editor 